\title{
Corticotropin-releasing hormone in the teleost stress response: rapid appearance of the peptide in plasma of tilapia (Oreochromis mossambicus)
}

\author{
P P L M Pepels, H van Helvoort, S E Wendelaar Bonga and \\ P H M Balm
}

Department of Animal Physiology, Faculty of Sciences, University of Nijmegen, Toernooiveld 1, 6525 ED Nijmegen, The Netherlands

(Requests for offprints should be addressed to P P L M Pepels; Email: ppepels@sci.kun.nl)

\begin{abstract}
High concentrations (up to $600 \mathrm{pg} / \mathrm{ml}$ ) of corticotropinreleasing hormone $(\mathrm{CRH})$ were detected in plasma of the teleost fish Oreochromis mossambicus (tilapia) when screening peripheral tissues of tilapia exposed to stress. Notably, the plasma CRH response to stressors in tilapia is much more pronounced than that in higher vertebrates, such as rats. After characterisation by RIA, by spiking plasma with synthetic tilapia CRH and by methanol-acid extraction, it is concluded that the immunoreactive (ir) material in plasma represents tilapia $\mathrm{CRH}_{1-41}$. Results indicate that a $\mathrm{CRH}$-binding protein is absent in tilapia plasma.

Unstressed fish had plasma CRH levels under the limit of detection $(<2 \mathrm{pg} / \mathrm{ml})$, but following capture stress plasma CRH levels $(170-300 \mathrm{pg} / \mathrm{ml})$ as well as plasma cortisol levels $(120 \mathrm{ng} / \mathrm{ml})$ increased rapidly to plateau levels, which were reached after approximately $5 \mathrm{~min}$. Tilapia $\mathrm{CRH}_{1-41}$ tested at concentrations between $10^{-11}$ and $10^{-7} \mathrm{M}$ in vitro did not stimulate the cortisol release from interrenal tissue. Also pretreatment of interrenal tissue with $10^{-9} \mathrm{M}$ CRH did not sensitise the cortisolproducing cells to a subsequent ACTH challenge. Forty-
\end{abstract}

eight hours of net confinement or $48 \mathrm{~h}$ of cortisol treatment abolished the plasma CRH response and cortisol response to capture stress. The rapidity of the plasma $\mathrm{CRH}$ response and its inhibition after $48 \mathrm{~h}$ of stress or cortisol treatment point to release by central nervous tissue. Therefore the distribution of glucocorticoid receptors (GRs) in the brain and pituitary of tilapia was investigated. Main GR-ir cell clusters were found in the medial part (Dm) and posterior part of the dorsal telencephalon, in the preoptic region, in the inferior lobe of the hypothalamus and in the cerebellum.

We conclude from comparison of $\mathrm{CRH}$ brain contents of unstressed and stressed fish that plasma $\mathrm{CRH}$ was released by CRH-ir cells located in the lateral part of the ventral telencephalon (Vl), and suggest that the cortisol feedback on $\mathrm{CRH}$ release by $\mathrm{Vl}$ is mainly exerted via the forebrain $\mathrm{Dm}$ region. We propose that $\mathrm{CRH}$ is mobilised during stress to fulfil peripheral functions, such as the regulation of circulating leukocytes or of cardiac output, as $\mathrm{CRH}$ receptors have been reported in these organs for fish species.

Journal of Endocrinology (2004) 180, 425-438

\section{Introduction}

The physiological role of circulating corticotropinreleasing hormone $(\mathrm{CRH})$ in mammals is generally considered to be restricted to defined periods, e.g. the third trimester in human pregnancy (McLean et al. 1995). Under normal conditions human plasma CRH levels are low (less than $20 \mathrm{pg} / \mathrm{ml}$; Linton et al. 1995, McLean et al. 1995, Catalan et al. 1998), and near the detection limit of methods available. Although lower vertebrates share many characteristics with mammals with respect to the neuroendocrine stress response (Wendelaar Bonga 1997), the role of CRH may be more versatile in lower vertebrates as it has been suggested that an evolutionarily old CRH system triggers migratory behaviour in some fish species and metamorphosis in amphibians (Denver 1997).
The present study further investigates the involvement of $\mathrm{CRH}$ in the regulation of the hypothalamus-pituitaryinterrenal axis in fish. Previously, our group has shown in the teleost fish tilapia (Oreochromis mossambicus) that during acute stress plasma cortisol concentrations increase extremely rapidly, in the absence of a preceding plasma adrenocorticotropin (ACTH) surge (Balm et al. 1994). Subsequently, the cDNA sequence of the tilapia $\mathrm{CRH}(\mathrm{tCRH})$ preprohormone demonstrated that more variation exists between vertebrate $\mathrm{CRH}$ sequences than previously recognised (van Enckevort et al. 2000), which together with the remarkably wide distribution of $\mathrm{CRH}$ in non-hypophysiotrophic brain centres of tilapia indicated that the role of $\mathrm{CRH}$ in this species may indeed be broader than previously thought (Pepels et al. 2002a,b). 
A question unresolved in lower vertebrates is the presence of circulating CRH. Suess et al. (1986) reported in the white sucker fish (Catostomus commersoni) circulating levels of urotensin-I (U-I), another member of the CRHlike family of peptides. In vitro, U-I stimulated the release of cortisol from the interrenal tissue located in the headkidneys of saltwater- but not freshwater-adapted flounder (Platichthys flesus) (Kelsall \& Balment 1998).

We here report $\mathrm{CRH}$ immunoreactivity (ir) in the plasma of tilapia, and we tested whether tCRH can act directly on the in vitro cortisol release from the headkidneys. Subsequently we investigated whether an acute stressor or a chronic stressor $(48 \mathrm{~h})$ affected the release of $\mathrm{CRH}$ into the blood. The brain area from which CRH is released into the circulation was determined by comparing the CRH content of brain regions before and after stress. Finally, to investigate whether cortisol affected the plasma CRH release via receptors in the brain, fish were treated with cortisol and the distribution of glucocorticoid receptors (GRs) in the brain was mapped.

\section{Materials and Methods}

\section{Animals}

Tilapia (O. mossambicus), between 1 and 2 years old, from our laboratory stock were kept in groups $(n=6$ or 7$)$ of mixed sex in $100-$ litre aquaria filled with tap water $\left(24^{\circ} \mathrm{C}\right)$ in a $12 \mathrm{~h}$ light : $12 \mathrm{~h}$ darkness regime. Fish were fed twice a day (0930 and $1530 \mathrm{~h}$ ) with Tetramin tropical fish food and were left undisturbed for 6 weeks before the start of the experiments. Fish were last fed on the day prior to killing. Sampling of the fish started between 1030 and $1130 \mathrm{~h}$. In most cases, fish were captured sequentially using a fishnet (Balm et al. 1994, Pepels et al. 2002b). The research was approved by the Institution's Animal Care and the National Animal Ethical Committee and conformed to the guidelines of the UFAW (Universities Federation for Animal Welfare).

\section{Plasma and tissue preparation}

Blood was collected from the caudal vessels into ice-cold glass capillaries containing $\mathrm{Na}_{2}$ EDTA and aprotinin ( $1.5 \mathrm{mg} \mathrm{Na} \mathrm{NaDTA}_{2}$ and $3000 \mathrm{kIU}$ aprotinin/ml blood) (Serva, Heidelberg, Germany). From fish weighing more than $100 \mathrm{~g}$ blood was taken with a syringe containing $\mathrm{Na}_{2}$ EDTA and aprotinin. In both cases blood was taken from the caudal vessels at a position anterior to the tenth caudal vertebra. Plasma was obtained by centrifugation at $10000 \mathrm{~g}$ for $5 \mathrm{~min}$ at $4{ }^{\circ} \mathrm{C}$, and frozen at $-20^{\circ} \mathrm{C}$ until RIA analysis for $\mathrm{CRH}$ or cortisol. In one case the cell fraction (from $1 \mathrm{ml}$ blood) was resuspended in a mixture $(1: 3 \mathrm{v} / \mathrm{v})$ of methanol and $0 \cdot 1 \mathrm{M} \mathrm{HCl}$ (containing $250000 \mathrm{kIU}$ aprotinin (Bayer) and $6 \mathrm{mM}$ ascorbic acid), incubated for $15 \mathrm{~min}$ at $0{ }^{\circ} \mathrm{C}$ and then vortexed for $1 \mathrm{~min}$. Following centrifugation the supernatant was vacuum dried and resuspended in RIA buffer. This procedure was repeated once. Both supernatants/extracts were analysed for CRH as described by Pepels et al. (2002b).

Pituitaries and brains were removed from the skull and immediately frozen and kept at $-20{ }^{\circ} \mathrm{C}$ until further micro-dissection. Brain micro-dissection was carried out on an ice-cooled Petri dish using $\times 5$ binocular magnification as described previously (Pepels et al. 2002b). For the present study, the telencephalon was transected into an anterior part containing the anterior-lateral subdivisions of the dorsal telencephalon (Da and Dla), and a posterior part containing the lateral part of the ventral telencephalon (Vl) (Pepels et al. 2002a). The caudal end of the olfactory bulbs was used as a transection landmark. Brain tissue homogenisation and analysis for $\mathrm{CRH}$ were carried out according to Pepels et al. $(2002 a, b)$.

\section{Effects of acute and confinement stress (experiments 1 and 2)}

Experiment 1 investigated whether $\mathrm{CRH}$ could be measured in plasma of stressed fish. Five male tilapia fish from different mixed-sex tanks were captured. Fish were individually isolated in small transparent tanks $(25 \mathrm{~cm}$ length, $15 \mathrm{~cm}$ depth, $15 \mathrm{~cm}$ height; containing 2 litre of water) for $12 \mathrm{~min}$, after which period blood was sampled.

Experiment 2 studied the stress response elicited by sequentially capturing fish ('acute stress') from a group (Balm et al. 1994, Quabius et al. 1997) and the modulation of this response by previous chronic stress $(48 \mathrm{~h}$ net confinement). Six fish from a tank were captured at $-48 \mathrm{~h}$ and stressed by confinement in a small net. At $\mathrm{t}=0 \mathrm{~h}$ tilapia from a control group $(n=6)$ and from the confined group were sampled sequentially in alternating order at time intervals $0,2,5,8,11$ and $14 \mathrm{~min}$. This experiment was repeated twice, yielding $n=3$ per sampling time point.

\section{Characterisation of plasma CRH (experiment 3)}

The CRH content of plasma (or of brain or pituitary homogenates) was determined by a RIA previously validated for tCRH (Pepels et al. 2002b). This RIA uses synthetic tCRH as a standard and the level of detection is $2 \mathrm{pg} /$ tube. Standard curves made in RIA buffer or in a mixture $(1: 3 \mathrm{v} / \mathrm{v})$ of methanol and $0.1 \mathrm{M} \mathrm{HCl}$ (containing $250000 \mathrm{kIU}$ aprotinin (Bayer) and $6 \mathrm{mM}$ ascorbic acid) yielded a similar sensitivity and $\mathrm{ED}_{50}$. The efficiency of $\mathrm{CRH}$ extraction from the plasma according to the method of Linton et al. (1995) was determined as follows. Plasma samples $(n=6)$ obtained from a fish group $(n=6$, weight $61 \pm 2 \mathrm{~g}$ ) sampled over a period of $12 \mathrm{~min}$, were each divided into two aliquots, one of which was measured directly and the other one was extracted by adding three times the volume of ice-cold methanol 
(Merck, Darmstadt, Germany). After incubation on ice for $15 \mathrm{~min}$, vortexing for $1 \mathrm{~min}$ and centrifugation $(10000 \mathrm{~g}$, $5 \mathrm{~min}, 4^{\circ} \mathrm{C}$ ) the supernatant was dried under vacuum and resuspended in RIA buffer to achieve its original volume.

A plasma pool from control fish from experiment 2 that were caught between 8 and 14 min was used in the CRH RIA to construct a dilution curve. The plasma from fish caught prior to $8 \mathrm{~min}$ from experiment 2 was used to assess the recovery of synthetic tCRH added to the plasma (spikes of 45 or $75 \mathrm{pg}$ tCRH). Further dilution curves were constructed using telencephalic brain tissues and pituitaries from undisturbed fish $(n=3)$, which were homogenised, methanol extracted and pooled as described previously (Pepels et al. 2002b).

To investigate whether U-I interfered in the plasma measurement, the influence of an abundant amount $(50 \mathrm{ng})$ of white sucker fish (C. commersoni) U-I on the $\mathrm{CRH}$ signal was tested.

\section{Plasma CRH levels in undisturbed fish (experiment 4)}

In order to obtain plasma samples from undisturbed fish, one fish was quickly caught from each of three control tanks within $1 \mathrm{~min}$. This was repeated on the next two alternate days to obtain plasma from nine undisturbed fish $(37 \pm 2 \mathrm{~g})$. Previously this procedure was shown to yield plasma samples containing low plasma cortisol levels (Quabius et al. 1997). As CRH levels turned out to be near the detection level in these samples $(25 \mu \mathrm{l})$ we quantified the amount of $\mathrm{CRH}$ in $1 \mathrm{ml}$ methanolextracted plasma from undisturbed tilapia. This extract was vacuum dried and resuspended in $100 \mu$ mixture of methanol and $\mathrm{HCl}(3: 1 \mathrm{v} / \mathrm{v})$ containing ascorbic acid $(6 \mathrm{mM})$ and aprotinin (Bayer: $250000 \mathrm{kIU} / \mathrm{l})$.

\section{In vitro cortisol release/superfusion of headkidneys} (experiment 5)

Headkidney tissues (containing the cortisol-producing interrenal cells) were removed from the fish immediately following sacrifice $(n=24,43 \pm 1 \mathrm{~g})$. Tissue from one fish was placed in each superfusion chamber (volume $650 \mu \mathrm{l}$ ) and superfused with superfusion medium (Balm et al. 1994), which contained $6 \mathrm{mM}$ ascorbic acid. After the cortisol release had reached a steady state headkidneys were superfused for $30 \mathrm{~min}(240-270 \mathrm{~min})$ with superfusion medium containing $0 \mathrm{M}(n=6), 10^{-7} \mathrm{M}(n=6)$, $10^{-9} \mathrm{M}(n=6)$ or $10^{-11} \mathrm{M}(n=6)$ of synthetic $\mathrm{tCRH}_{1-41}$ (synthesised by Dr J Rivier, Salk Institute, La Jolla, CA, USA). The headkidneys which had received control medium $(0 \mathrm{M})$ or $10^{-9} \mathrm{M}$ CRH were subsequently (300-315 min) pulsed with $10^{-10} \mathrm{M}$ human ACTH (Peninsula, Merseyside, UK). This sub-optimal concentration of ACTH was chosen as the use of higher concentrations of ACTH could mask the possible effect of $\mathrm{CRH}$ due to an exhaustion of intracellular second messenger pools or enzymes needed for cortisol synthesis. The application of the ACTH challenge $30 \mathrm{~min}$ after the $\mathrm{CRH}$ pulse was based on previous in vivo results during and after acute stress caused by capture. First CRH (this study), and then, more than 15 min later, plasma ACTH levels will increase (Balm et al. 1994). Superfusion fractions were collected and stored at $-20^{\circ} \mathrm{C}$ until cortisol analysis by RIA as described previously (Balm et al. 1994). From three additional tilapia ( $\pm 400 \mathrm{~g}$ body weight) headkidneys, weighing $205 \mathrm{mg}$ on average, were homogenised in methanol and $\mathrm{HCl}(3: 1 \mathrm{v} / \mathrm{v})$ containing ascorbic acid $(6 \mathrm{mM})$ and aprotinin (Bayer: $250000 \mathrm{kIU} / \mathrm{l})$ and further treated for analysis in the CRH RIA as described previously (Pepels et al. 2002b).

\section{Cortisol treatment (experiment 6)}

Tilapia (group size seven) were fed for $48 \mathrm{~h}$ with Tetramin food, either sprayed with ethanol alone (control tank) or with cortisol-containing ethanol (Balm et al. 1994). The fish received a daily food ration of $1.5 \%$ of their body weight, thereby receiving a dose of $30 \mathrm{mg}$ cortisol $/ \mathrm{kg}$ body weight. At $48 \mathrm{~h}$, sampling started by catching control and cortisol-treated fish in alternating sequence at $\mathrm{t}=0$ and thereafter at each time interval: 2, 5, 8, 11, 14 and $18 \mathrm{~min}$. Blood was immediately sampled after catching. This experiment was repeated eight times (in two cases one additional control group was sampled), yielding $n=11$ controls and $n=9$ cortisol-treated groups. Plasma samples from fish (from all the trials, total number of fish $=140$, weight $34 \pm 1 \mathrm{~g}$ ) were analysed for CRH and cortisol. The pituitary homogenates were also analysed for CRH. From six out of nine experiments, the brains of fish numbers 1, 2, 6 and 7 were dissected, homogenised and analysed for $\mathrm{CRH}$ to investigate whether stress affected the $\mathrm{CRH}$ content of brain regions within 14-18 min.

\section{Immunohistochemistry}

Sections for GR and CRH immunostaining were from brains which have also been used to construct a tilapia brain atlas (Pepels et al. 2002a). Staining procedures were done directly after sectioning of freshly fixed brains. GR-ir was performed using sections adjacent to the ones used to construct the tilapia CRH brain atlas and GR-positive cells were plotted in chart drawings of this tilapia brain atlas. The fish $( \pm 30 \mathrm{~g})$ had been perfused with $0 \cdot 9 \%$ saline for $1 \mathrm{~min}$ and then for $10 \mathrm{~min}$ with Bouin's fluid. Brains had been sectioned (transversally or sagitally, $10 \mu \mathrm{m}$ sections) and every 15th section was mounted and stained for GR-ir and the adjacent sections for $\alpha$-melanocytestimulating hormone $(\alpha-\mathrm{MSH})$ (Antibody code L9; Pepels et al. 2004). The GR antibody has previously been used to study GR in tilapia (Dang et al. 2000) and was a generous gift from Dr B Ducouret (Endocrinologie Moleculaire de la Reproduction, University of Rennes, France). 

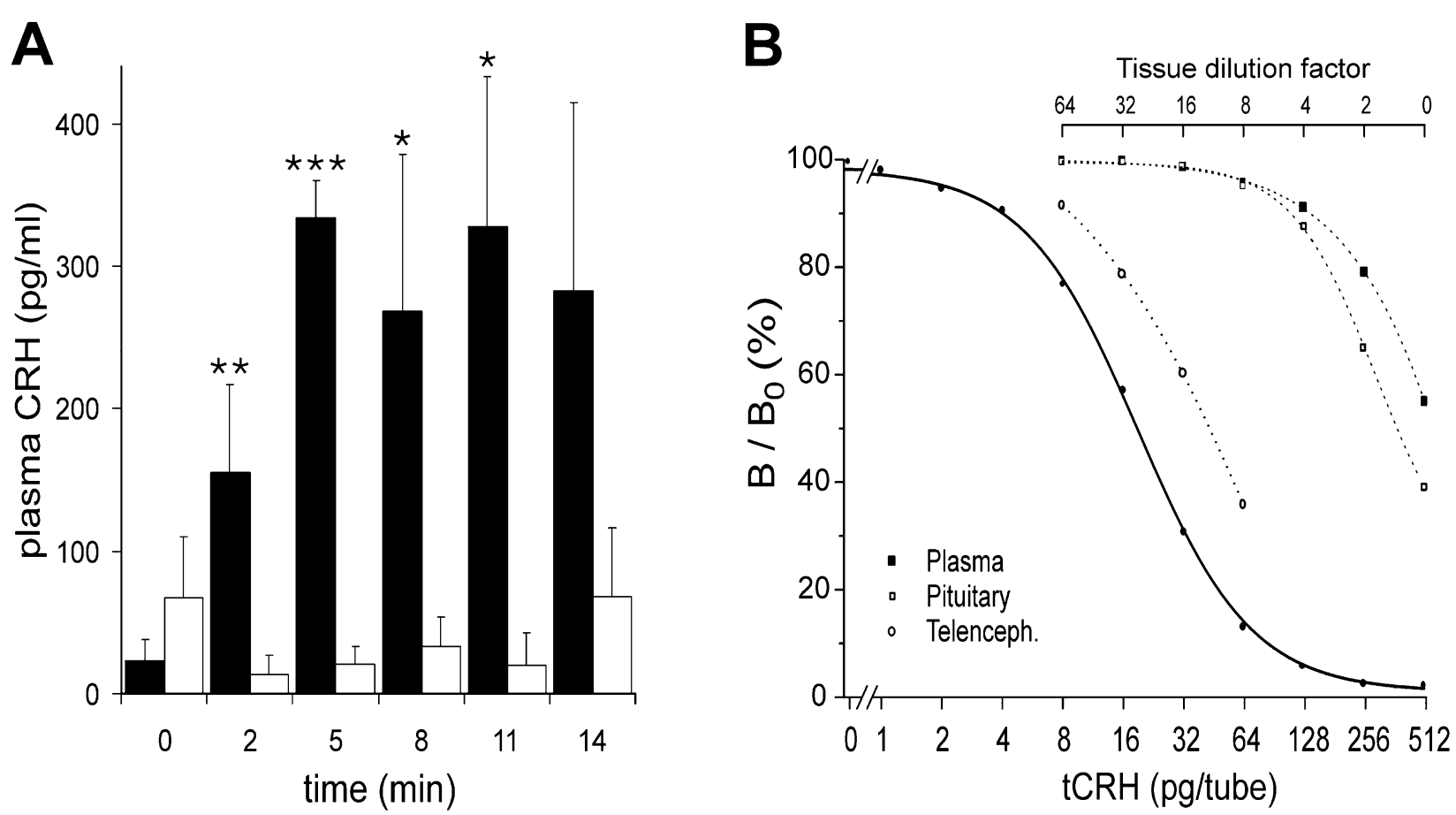

Figure 1 (A) Effect of capture (acute stress) on plasma CRH levels of control fish (black bars), $n=3$, and 48 h-confined fish (open bars), $n=3$. (B) CRH RIA standard curve and displacement of radiolabelled tracer from the antibody by serial dilutions of a neat plasma pool obtained from stressed tilapia (8-14 min acute capture stress, same fish as in (A)) and dilutions of pituitary and telencephalon extracts (methanol-acid extraction). At each sampling time point the control group was compared with the confined group. $P$ values $<0 \cdot 05,<0 \cdot 02$ and $<0.01$ are represented as ${ }^{*},{ }^{* *}$ and ${ }^{* * *}$ respectively. Means \pm S.E.M.

This antibody is directed against the ab-domain of the trout GR1 receptor (Tujague et al. 1998, Bury et al. 2003). A section in this ab-domain shares a high degree of homology with the corresponding region of both Haplochromis burtoni GRs. Although to date no complete GR sequences are known in tilapia (Tagawa et al. 1997), $H$. burtoni and tilapia amino acid sequences are 99\% identical (A K Greenwood, unpublished observation). The GR antibody was diluted 2500 times and sections were further processed and treated as described Pepels et al. (2002a) with the only exception that the avidin-biotin complex (Vectastain ABC Reagent; Vector Laboratories, Burlingame, CA, USA) was used at a dilution of 1:200. Omission of the primary antibody abolished the immunoreactivity signal. The $\alpha-\mathrm{MSH}$ antibody was 1000 times diluted. No ABC enhancer was used but otherwise the same procedure as for GR was used.

The distance from the rostral tip of the olfactory bulb is represented at each brain level (see Fig. 4) and corresponds to the levels represented in the tilapia CRH brain atlas of Pepels et al. (2002a).

\section{Statistics}

All data are represented as means \pm S.E.M. Differences between groups and treatments of experiments 2 and 6 were analysed with the two-tailed Student's $t$-test (unpaired) and $P<0.05 \%$ was accepted as the level of significance. $P<0 \cdot 05,<0 \cdot 02$ and $<0 \cdot 01$ are represented as $*, * *$ and $* * *$ respectively. Plateau levels of plasma CRH or plasma cortisol (experiments 2 and 6) were calculated by taking the mean plasma hormone level of tilapia caught in the time period 5-14 min per tank. In experiment 5 the two-tailed Student's $t$-test was used pair-wise to test differences between prepulse cortisol release rates with maximally stimulated release.

\section{Results}

Plasma of fish that were kept in isolation for $12 \mathrm{~min}$ contained $590 \pm 109 \mathrm{pg} / \mathrm{ml} \quad(n=5$; experiment 1$)$ of $\mathrm{CRH}$-like immunoreactivity. In experiment 2 , sequentially capturing fish from a group resulted in a time-dependent increase in plasma CRH-like immunoreactivity (Fig. 1A). In fish caught first, CRH levels were low and in most cases below the level of detection. Plateau levels of plasma CRH $(302 \pm 54 \mathrm{pg} / \mathrm{ml})$ in control fish caught between 5 and 14 min were higher than the $\mathrm{CRH}$ plasma levels $(36 \pm 14 \mathrm{pg} / \mathrm{ml})$ in $48 \mathrm{~h}$ confined fish $(P<0 \cdot 001)$, in which a plasma $\mathrm{CRH}$ response was absent (Fig. 1A). 
Table 1 Effects of $\mathrm{CRH}$ alone or in combination with $10^{-10} \mathrm{M} \mathrm{ACTH}$ on headkidney cortisol release $(n=6)$. Values represent maximally stimulated release minus prepulse release ( $\mathrm{pg} / \mathrm{min}$ per $\mathrm{g}$ body weight). Prepulse release at $240 \mathrm{~min}$ was $0 \cdot 38 \pm 0 \cdot 06(n=24)$ and prepulse release at $290 \mathrm{~min}$ was $0 \cdot 17 \pm 0 \cdot 04(n=12)$

\begin{tabular}{|c|c|c|c|c|}
\hline & \multicolumn{4}{|l|}{ Molarity of CRH } \\
\hline & 0 & $10^{-11}$ & $10^{-9}$ & $10^{-7}$ \\
\hline CRH 240-270 min & $-0.06 \pm 0.05$ & $0 \cdot 17 \pm 0 \cdot 17$ & $0 \cdot 04 \pm 0.03$ & $0 \cdot 08 \pm 0 \cdot 15$ \\
\hline АСТН $300-315 \mathrm{~min}$ & $3 \cdot 77 \pm 1 \cdot 45^{*}$ & ND & $4 \cdot 31 \pm 1 \cdot 92^{*}$ & ND \\
\hline
\end{tabular}

$\mathrm{ND}=$ not determined.

*Maximally stimulated release significantly different from prepulse release rates.

During characterisation, supernatants obtained from the blood cell fraction of acutely stressed fish from experiment 2 did not contain detectable amounts of CRH. Serial dilutions of neat (unextracted) plasma of these fish displaced radiolabelled tCRH from the antibody in a parallel fashion to the curves obtained with dilutions of synthetic tCRH $\mathrm{C}_{1-41}$ (standard) and to the curve obtained with serial dilutions of tilapia pituitary or telencephalic brain tissue homogenates (Fig. 1B). Spikes of synthetic tCRH (45, $75 \mathrm{pg}$ ) added to neat plasma (pooled plasma samples of unstressed tilapia) were recovered with an efficiency of 95 and $104 \%$ respectively. Plasma samples $(n=6)$ from a fish group sampled over a period between 1 and $12 \mathrm{~min}$ containing $\mathrm{CRH}$ in concentrations ranging from 2 to $173 \mathrm{pg} / \mathrm{ml}$ had similar amounts of CRH with or without methanol extraction $(98.9 \pm 6 \cdot 7 \%)$.

In experiment 3 , addition of $50 \mathrm{ng}$ U-I to the standard and plasma samples did not affect displacement of tracer from the antibody as, first, the measured value of $\mathrm{CRH}$ in plasma samples to which $50 \mathrm{ng}$ U-I was added was indistinguishable $(105 \pm 15 \%)$ from that measured in the absence of U-I. Secondly, in both the presence or absence of $50 \mathrm{ng} \mathrm{U-I}$, the plasma dilution curves ran parallel to the standard curve and yielded similar $\mathrm{ED}_{50}$ values (not shown). In both cases a similar amount of tCRH was needed to displace $50 \%$ of the bound radiolabel $\left(\mathrm{ED}_{50}\right)$.

In experiment 4, a dilution curve of a methanolextracted plasma pool could not be distinguished from the curve obtained with dilutions of the neat plasma pool. The plasma cortisol and CRH levels in the undisturbed fish $(n=9)$ caught were $4 \pm 1 \mathrm{ng} / \mathrm{ml}$ and $5 \pm 5 \mathrm{pg} / \mathrm{ml}$ respectively, with eight out of nine fish below the level of detection. Even in the equivalent of $1 \mathrm{ml}$ plasma from unstressed tilapia (which was methanol extracted and vacuum dried to obtain a small volume for RIA measurement) the CRH level was under the limits of detection.

tCRH tested in vitro at concentrations of $10^{-11}, 10^{-9}$ and $10^{-7} \mathrm{M}$ did not stimulate the release of cortisol from tilapia headkidney (experiment 5; Table 1). There was no difference in ACTH-stimulated $\left(10^{-10} \mathrm{M}\right)$ cortisol release rates between headkidneys which beforehand had received $0 \mathrm{M}$ or $10^{-9} \mathrm{M} \mathrm{CRH}$ (Table 1). Headkidney homogenates from undisturbed fish $(n=3)$ contained $52 \pm 11 \mathrm{pg} /$ headkidney of CRH-ir.

In an attempt to mimic the effects induced by $48 \mathrm{~h}$ of confinement stress, fish were treated with cortisol (experiment 6; Figs 2 and 3). In the control fish (Fig. 2A) highest plasma CRH levels were measured in the sampling time period between 10 and $12 \mathrm{~min}$, after which period the CRH concentration decreased $(P<0.001 ; \mathrm{t}=12 \mathrm{vs}$ $\mathrm{t}=18 \mathrm{~min})$. No differences in plasma CRH plateau levels between males or females were detected (males $173 \pm 26 \mathrm{pg} / \mathrm{ml}$; females $164 \pm 29 \mathrm{pg} / \mathrm{ml}$ ), nor between females in different reproductive stages (late egg stage females $150 \pm 49 \mathrm{pg} / \mathrm{ml}$ vs early egg stage $169 \pm 34 \mathrm{pg} /$ $\mathrm{ml}$ ). Forty-eight hours of cortisol feeding inhibited the increase in plasma $\mathrm{CRH}$ levels during the period of 4-12 min after the start of capture (Fig. 2A). In control fish, plasma CRH plateau levels were $168 \pm 19 \mathrm{pg} / \mathrm{ml}$ (Fig. 2A) and cortisol levels reached plateau levels of $118 \pm 16 \mathrm{ng} / \mathrm{ml}$ (Fig. 2B). In the $48 \mathrm{~h}$ cortisol-fed fish (Fig. 2) the plasma CRH response (plateau levels of $70 \pm 10 \mathrm{pg} / \mathrm{ml})$ was inhibited $(P<0.001$ in comparison with control value) and the plasma cortisol response (plateau levels of $9 \pm 2 \mathrm{ng} / \mathrm{ml})$ was absent $(P<0 \cdot 001$ in comparison with control value).

Comparison of the CRH brain content (experiment 6; Fig. 3A) of control fish caught in the first $2 \min (n=12)$ with that of control fish caught between 14 and $18 \mathrm{~min}$ $(n=12)$, revealed that the latter fish had more $\mathrm{CRH}$ $(P<0.05)$ in the anterior part of the telencephalon (containing the Dl region), but less CRH $(P<0.05)$ in the posterior part of the telencephalon (containing the Vl region). Both effects were absent in cortisol-pretreated fish (Fig. 3B). No effects of capture order in both control and cortisol-pretreated fish were observed in other brain regions (diencephalon, tectum and rhombencephalon; Fig. $3 \mathrm{~A}$ and $\mathrm{B}$ ).

\section{Immunohistochemistry}

To investigate whether the inhibitory effect of cortisol on CRH release could be mediated via GRs, the GR-ir cells and cell clusters in the brain were localised. The 

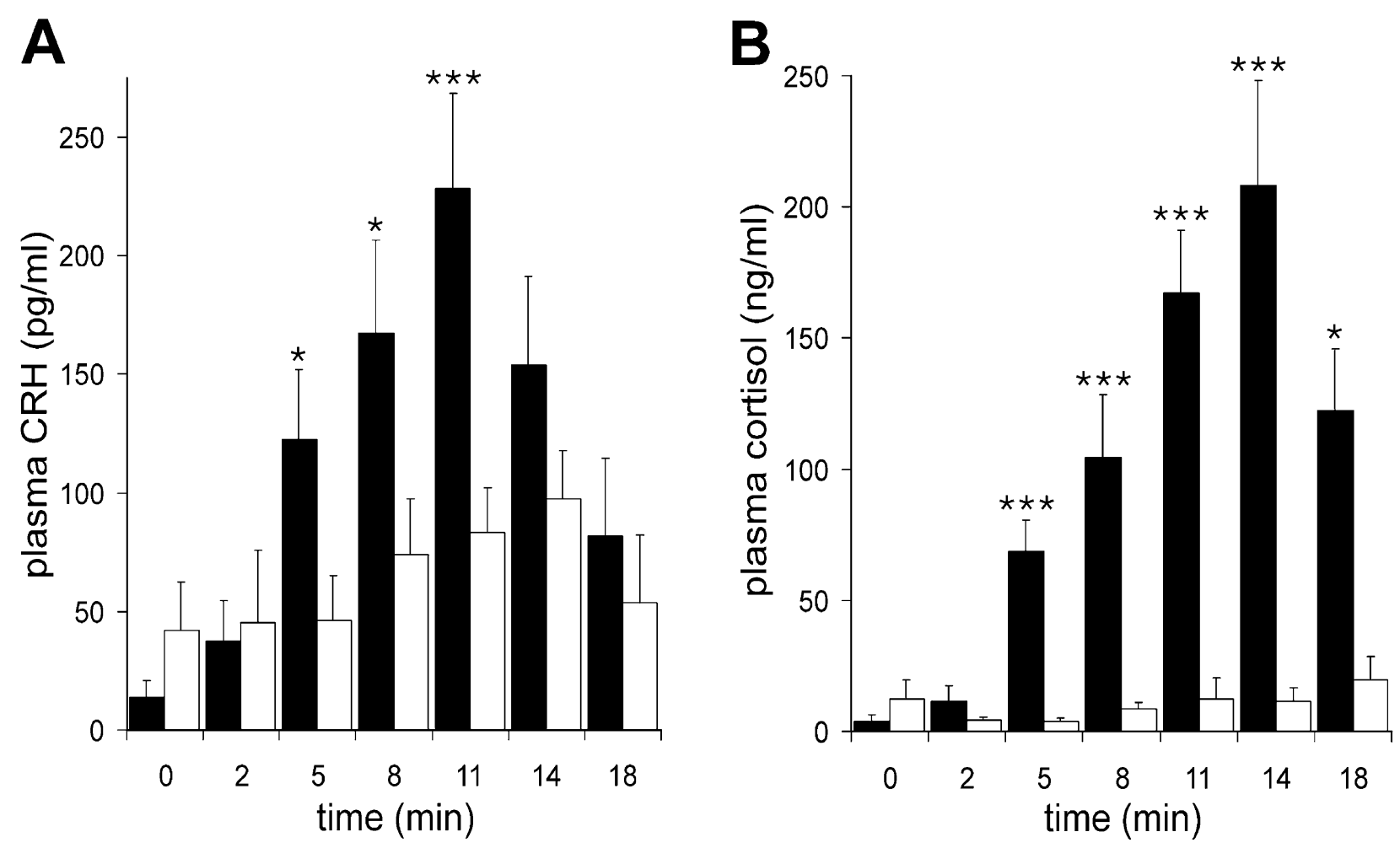

Figure 2 Effect of capture (acute stress) on plasma CRH levels (A) or on plasma cortisol levels (B) of control fish (black bars), $n=11$, or cortisol-fed fish (open bars), $n=9$. At each sampling time point the control group was compared with the cortisol-pretreated groups. $P$ values $<0.05$ and $<0.01$ are represented as * and ${ }^{* * *}$ respectively. Means \pm S.E.M.

GR-ir-positive staining was detected in the cytoplasm of cells. The brain of tilapia contained five major ir-cell clusters, three of which were located in the telencephalon, one in the diencephalon and one in the cerebellum. Together these cell clusters contained approximately $75 \%$ of the total number of GR-ir cells found in the brain. All other GR-ir areas mentioned contained less cells than found in the cell clusters and these few cells were often scattered throughout the areas.

The GR-positive cell clusters are presented in a rostrocaudal direction. The first cluster located in the dorsal subdivision of the medial part of the dorsal telencephalon (Dmd; Fig. 4: 1250 and $1550 \mu \mathrm{m}$, Fig. 5A and E) consisted of a large number of large round cells $(11 \mu \mathrm{m})$, some of which were situated close to the ependyma (Fig. 4: 1250 and $1550 \mu \mathrm{m})$. Colocalisation of GR and CRH was found only in a few large pyriform cells $(12 \mu \mathrm{m})$ located dorsal from the ventrolateral telencephalon (Fig. 4: $1550 \mu \mathrm{m}$, Fig. $5 \mathrm{~B}$ and $\mathrm{C})$. The $\mathrm{CRH}$-ir cells located in the ventrolateral telencephalon (Vl: Fig. 4: $1250 \mu \mathrm{m}$; Fig. 5C) were not GR-ir (Fig. 5B). The ventral telencephalon was conspicuously innervated by blood capillaries (Fig. 5A). In particular the Vl region was very rich in capillaries, which were often located near the CRH-ir cells (Fig. 5D). Some
GR-ir cells were also found in the supracommissural part of the ventral telencephalon, including Vs (Fig. 4: $1550 \mu \mathrm{m}$, Fig. 5A) and Vd.

The second GR-ir cell cluster consisted of round cells located in the posterior part of the dorsal telencephalon (Dp: Fig 4: $2150 \mu \mathrm{m}$ ).

The third GR-ir cell cluster was found in the preoptic region. The medial part of the anterior preoptic region (Pam: Fig. 4: $1550 \mu \mathrm{m}$ ) contained intensely stained parvocellular cells and the magnocellular preoptic nucleus (Pmc) contained intensely stained magnocellular cells (Fig. 4: 2150 and $2300 \mu \mathrm{m}$, Fig. 5 G). In the diencephalon small GR-ir cells $(5 \mu \mathrm{m})$ were found in the lateral and medial part of the nucleus tuberis lateralis (nltl, nltm; Fig. 4: $2300 \mu \mathrm{m}$, Fig. 5F) and in the posterior nucleus tuberis (npt: Fig. 4: $3050 \mu \mathrm{m}$ ). Close to the border of the nltm a few large GR-ir cells were present. Colocalisation of CRH-ir and GR-ir was observed in some parvocellular cells in the preoptic nucleus (npo) and the lateral tuberal nucleus (nlt) (not shown). The small cells found in the lateral and medial nucleus recessus lateralis were weakly stained (Fig. 4: $3050 \mu \mathrm{m}$ ).

A fourth cell cluster was situated in the central parts of the inferior lobe of the hypothalamus (LIH; Fig. 4: 

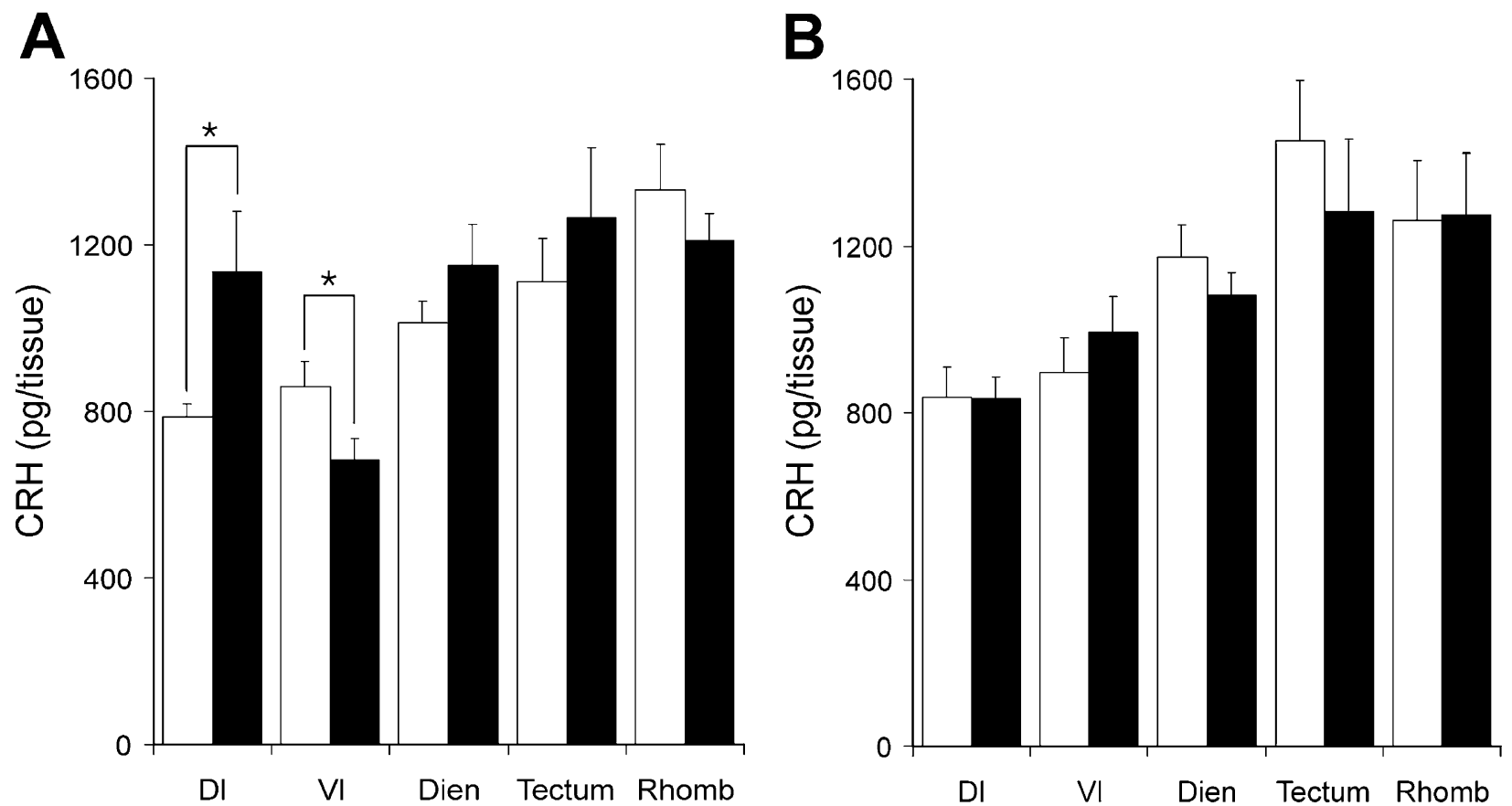

Figure 3 The $\mathrm{CRH}$ content of different brain regions of control fish (left panel), $n=12$, and of cortisol-fed fish (right panel), $n=12$. The $\mathrm{CRH}$ content of brain regions from the first captured fish (between 0 and $2 \mathrm{~min}$ ) are depicted in open bars and the CRH content of the last captured fish (between 14 and $18 \mathrm{~min}$ ) are depicted in black bars. $P$ values $<0.05$ are represented as *. Means \pm S.E.M. Rhomb, thrombencephalon; Dien, diencephalon.

$3050 \mu \mathrm{m})$, but also many neurons located near the ependyma of the inferior lobe were GR-ir-positive (Fig. 4: 2300 and $3050 \mu \mathrm{m}$ ). The tertiary gustatory nucleus (TGN; Fig. 4: $3050 \mu \mathrm{m}$ ), the central posterior thalamic nucleus (CP; Fig. 4: $3050 \mu \mathrm{m}$ ) and cells in the periventricular layer of the tectum mesencephali (tect: Fig. 4: $3050 \mu \mathrm{m})$ contained a few GR-ir cells, the latter of which were weakly stained.

In the cerebellum a fifth cell cluster consisting of Purkinje cells (ccP) was located in the lateral, ventral and medial fields (Fig. 4: $5150 \mu \mathrm{m}$ ). In the rhombencephalon some cells in the lateral and posterior part of the secondary gustatory nucleus (ngs) and in the reticular formation (ret) were GR-ir (Fig. 4: $5150 \mu \mathrm{m}$ ).

In the pituitary gland, GR-ir cells were found in the proximal pars distalis (Ppd; Fig. 4: $2150 \mu \mathrm{m}$ ), in the pars intermedia (Pi: Fig. 4: $2300 \mu \mathrm{m}$, Fig. 5I), but relatively few cells in the rostral pars distalis were GR-ir. From comparison of adjacent sections stained for GR or $\alpha-\mathrm{MSH}$ it appeared that subpopulations of the melanotrophs and the somatolactin (SL) cells (i.e. $\alpha-\mathrm{MSH}$-negative cells) were GR-ir (Fig. 5H and I).

\section{Discussion}

The high concentrations of plasma CRH in the teleost fish O. mossambicus (tilapia) after exposure to an acute stressor represent the first report of plasma CRH levels in lower vertebrates. It should be noted that the increase of CRH in peripheral plasma from stressed tilapia (up to $600 \mathrm{pg} / \mathrm{ml}$ ) is dramatic and much more pronounced than in rats (from $8 \mathrm{pg} / \mathrm{ml}$ in controls up to $18 \mathrm{pg} / \mathrm{ml}$ after ether-laparotomy or water immersion stress; Nishioka et al. 1993), or in humans under pathophysiological conditions, such as major depression (23 vs $9 \mathrm{pg} / \mathrm{ml}$ in healthy persons (Catalan et al. 1998)). Highest plasma CRH levels have been reported in peripheral plasma from pregnant women during their third trimester of pregnancy $( \pm 1-1.5 \mathrm{ng} / \mathrm{ml}$; Linton et al. 1995, McLean et al. 1995) and in pituitary portal blood ( $\pm 200 \mathrm{pg} / \mathrm{ml}$; Hauger et al. 1994). Interestingly, teleost fish do not possess a hypothalamicpituitary portal system, but hypothalamic neuropeptidergic neurons directly innervate proopiomelanocortinproducing target cells in the pituitary.

Previously we have shown that when tilapia are sampled sequentially from a group, high levels of plasma cortisol are rapidly reached within $5 \mathrm{~min}$, without a preceding rise in plasma ACTH (Balm et al. 1994). In the present study maximal plasma CRH levels were also rapidly reached within $5 \mathrm{~min}$, and as plasma CRH levels already decreased after $14 \mathrm{~min}$, we suggest that the rapid onset and decrease of the CRH response in tilapia indicates a rapidly released discrete pulse of CRH. The rapid decrease in plasma $\mathrm{CRH}$ peak in tilapia is consistent with the short half lives of many vertebrate neuropeptides including mammalian 

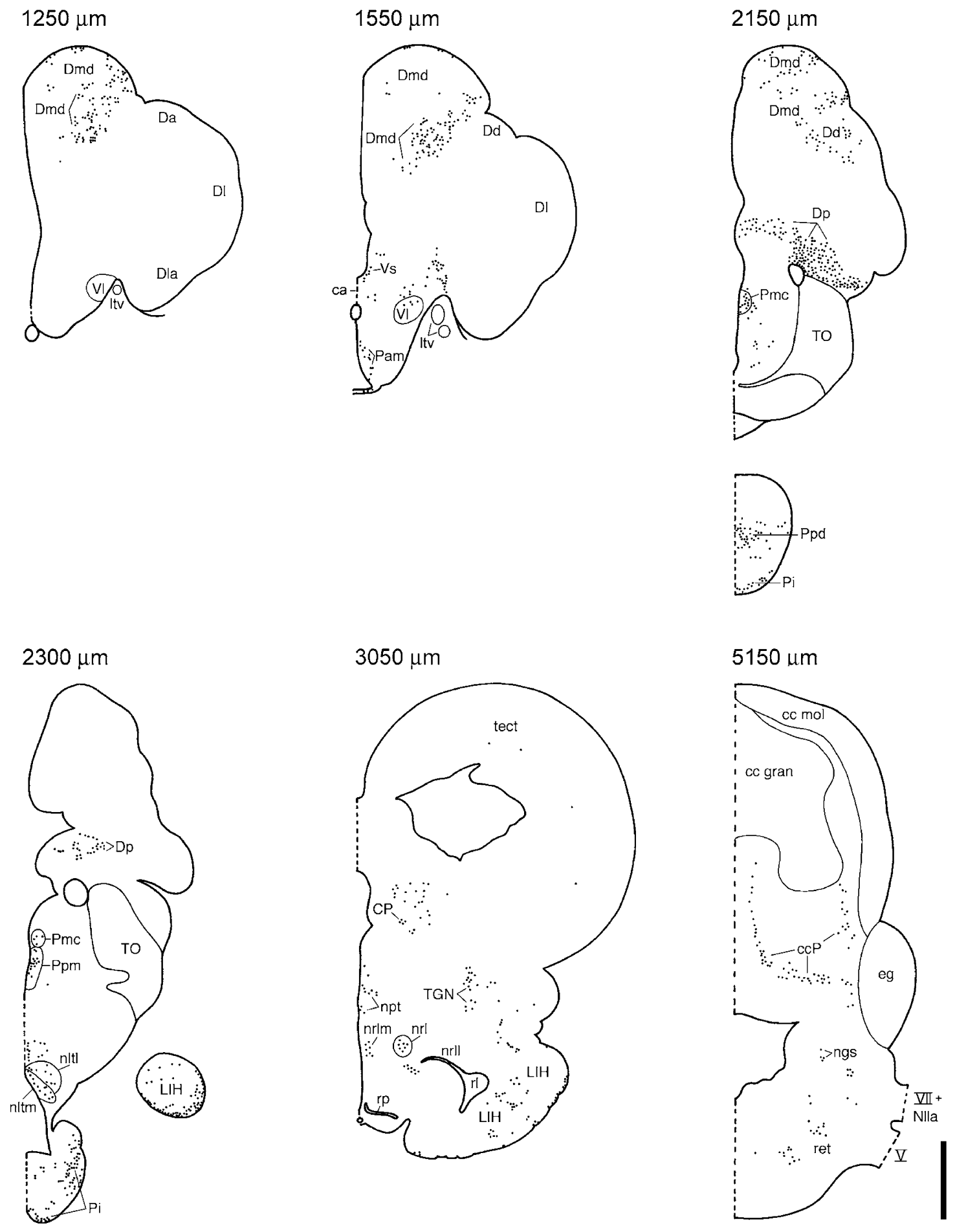
CRH, which has a half life of about $20 \mathrm{~min}$ in plasma (Stalla et al. 1986).

We conclude that the immunoreactive material in plasma from stressed fish represented $\mathrm{tCRH}_{1-41}$, as firstly dilution curves made from neat or methanol-extracted tilapia plasma ran parallel. Secondly, CRH levels were similar in neat or extracted plasma in an RIA previously validated for tCRH (Pepels et al. 2002b). Thirdly, exogenous CRH added to neat or extracted plasma yielded similar CRH values. In human plasma devoid of CRH, the existence of a CRH-binding protein (CRH-BP) was noticed when an unknown factor displaced radiolabelled $\mathrm{CRH}$ from the antibody in the RIA (Orth \& Mount 1987). Methanol extracts CRH, but not its binding protein (Linton et al. 1995). Since in our study no radiolabelled tCRH was displaced from the antibody by plasma from unstressed tilapia, tilapia plasma probably does not contain a CRH-BP. This is in line with the absence of CRH-BP in the plasma of Xenopus laevis, and with the suggestion made by Kemp et al. (1998) that plasma BP has been recruited relatively recently in evolution to fulfil a peripheral function, i.e. binding of placental $\mathrm{CRH}$ in primates. Chemical crosslinking studies with radiolabelled $X$. laevis $\mathrm{CRH}$ have suggested the presence of $\mathrm{BP}$ activity in brain tissue of birds, reptiles and fish such as tilapia (Seasholtz et al. 2002). Consistently, we previously demonstrated that $\mathrm{CRH}$ extraction from tilapia brain homogenates with methanol greatly increased the recovery when compared with acid extraction (Pepels et al. 2002b).

Although this study is the first to measure high levels of circulating $\mathrm{CRH}$, previously circulating U-I levels of $80 \mathrm{pg} / \mathrm{ml}$ have been reported in the white sucker fish $C$. commersoni (Suess et al. 1986). U-I, a member of the CRF-like family of peptides, is synthesised in teleost fish by neuroendocrine cells located in the caudal part of the spinal cord (Lovejoy \& Balment 1999) and in minor quantities by neurons in the brain (Suess et al. 1986, Bernier et al. 1999). Interference of plasma U-I can be discounted in our RIA (Pepels et al. 2002b), for which previously the crossreactivity with U-I was determined to be less than $0 \cdot 5 \%$. Possible contamination during blood sampling was minimised by taking blood from the caudal vessels anterior to the tenth terminal vertebrae. The U-I-secreting Dahlgrenn cells are located in the spinal cord in the area of the fifth caudal vertebrae (Fridberg et al. 1966). Importantly, addition of $50 \mathrm{ng}$ U-I to plasma of stressed tilapia did not alter the plasma $\mathrm{CRH}$-ir values measured $(105 \pm 15 \%)$.

The inhibition of the plasma CRH response after the cortisol treatment in our study suggests that this hormone is involved in the inhibition of the plasma CRH response observed after $48 \mathrm{~h}$ of confinement. Also in rats, treatment with dexamethasone reversibly decreased (from 13 to $8 \mathrm{pg} / \mathrm{ml}$ ) the plasma CRH levels (Sumitomo et al. 1987, Yokoe et al. 1988). As in these studies the plasma CRH alterations were reflected in hypothalamic and pituitary $\mathrm{CRH}$ levels, the authors strongly suggested that the main source of plasma CRH was the hypothalamic paraventricular nucleus (pvn) neurons with their terminals in the median eminence.

\section{Source of CRH and cortisol feedback}

In fish, some circulating neuropeptides, such as melanocortin-stimulating hormone and thyrotropin releasing hormone, are released from the neural part of the pituitary. However, we exclude the pituitary as a source of plasma $\mathrm{CRH}$ as no time-dependent changes were found in pituitary $\mathrm{CRH}$ content during capture. In the case that plasma CRH originated from the neural part of the pituitary gland, a detectable reduction of about $170 \mathrm{pg}$ of pituitary CRH content would have occurred (3\% of the body weight is plasma in tilapia (Okimoto et al. 1994)).

The rapidity of the $\mathrm{CRH}$ response in tilapia points to control by central nervous tissue. Previously we have shown that the largest population of CRH-ir cells in the brain of tilapia consists of non-hypophysiotrophic neurons, located in the lateral part of the ventral telencephalon (Vl). These cells have major projections to the anterior part of the laterodorsal telencephalon (Dla), but also locally in the Vl area CRH-ir terminals were observed (Pepels et al. 2002a). On the basis of the rapid decrease in CRH content of the posterior telencephalon, including Vl, during capture stress we propose the $\mathrm{Vl}$ as the source for circulating

Figure 4 Rostro-caudal series of transverse brain sections illustrating the distribution of GR-ir cells in the brain of tilapia (scale bar $=500 \mu \mathrm{m}$ ). The distance from the rostral tip of the olfactory bulb is indicated in $\mu \mathrm{m}$ for each level. These levels correspond to levels and sections previously described in a tilapia brain atlas (see Figure 1E, F, H, I, K, L and N in Pepels et al. 2002a). Abbreviations are: ca, commissura anterior; cc gran, granular layer of the corpus cerebelli; cc mol, molecular layer of the corpus cerebelli; ccP, Purkinje cell layer of the corpus cerebelli; $\mathrm{CP}$, central posterior thalamic nucleus; Da, pars dorsalis telencephali pars anterior; Dd, pars dorsalis telencephali pars dorsalis; Dl, pars dorsalis telencephali pars lateralis; Dla, anterior subdivision of Dl; Dmd, dorsal subdivision of the pars dorsalis telencephali pars medialis; Dp, pars dorsalis telencephali pars posterior; eg, eminentia granularis; LIH, lobus inferior hypothalami; Itv, lateral telencephalic veins; ms, meningeal surface; ngs, nucleus gustatorius secundarius; NLLa, anterior lateral line nerve; nltl, lateral part of the nucleus lateralis tuberis; nltm, medial part of the nucleus lateralis tuberis; npt, nucleus posterior tuberis; nrl, nucleus recessi lateralis; nrlm, medial part of nrl; Pam, medial part of the preoptic region pars anterior; Pi, pars intermedia of the pituitary gland; Pn, pars nervosa of the pituitary gland; Ppd, proximal pars distalis of the pituitary gland; Pmc, magnocellular preoptic nucleus; Ppm, medial part of the preoptic region; ret, reticular formation; $\mathrm{rl}$, recessus lateralis; $\mathrm{rp}$, recessus posterior; tect, tectum mesencephali; TGN, tertiary gustatory nucleus; $\mathrm{TO}$, tractus opticus; $\mathrm{V}$, nervus trigemius; $\mathrm{Vd}$, area ventralis telencephali pars dorsalis; Ve, ventricle; $\mathrm{VII}$, nervus facialis; $\mathrm{Vl}$, area ventralis telencephali pars lateralis; $V \mathrm{~s}$, area ventralis telencephali pars supracommissuralis. 


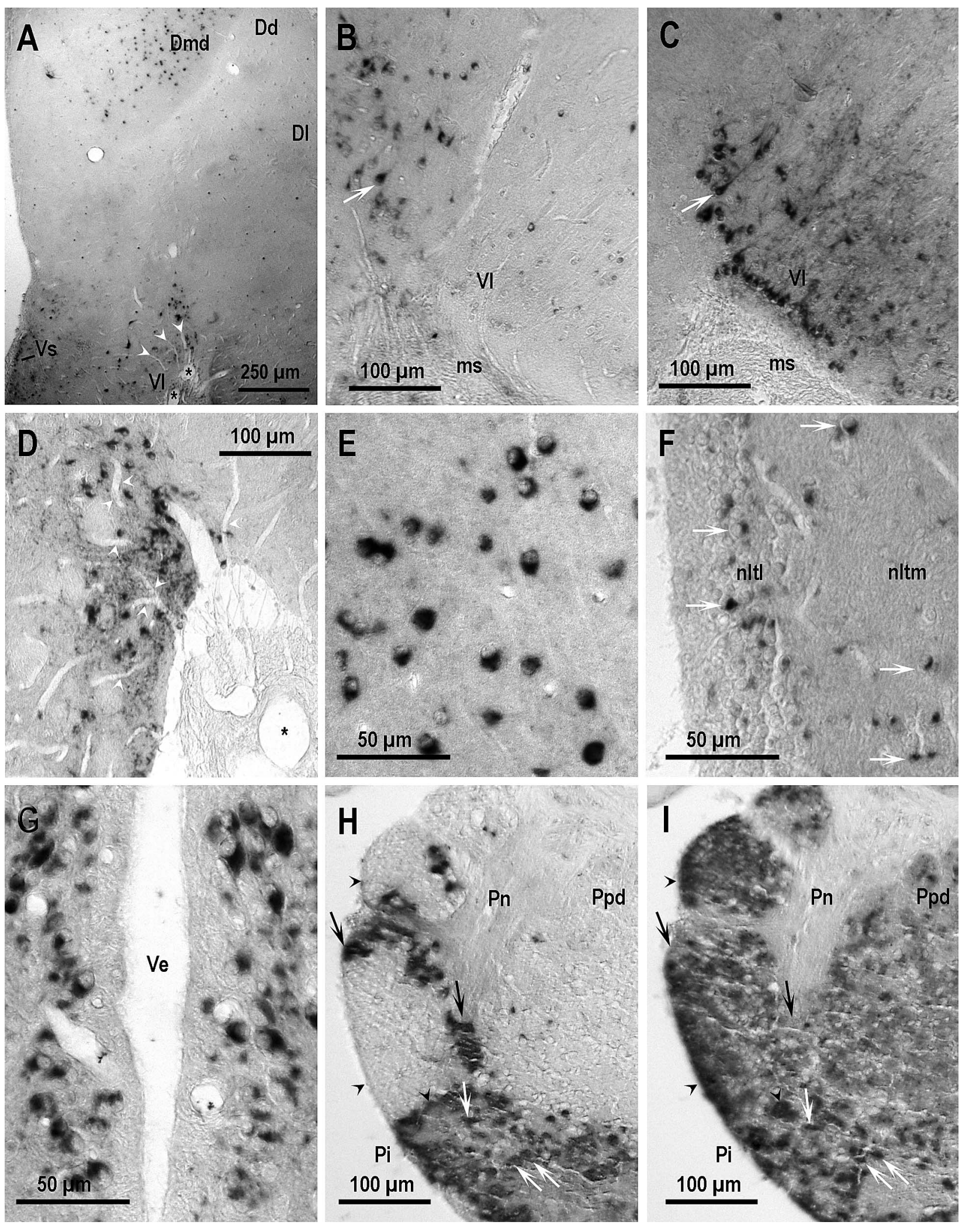


$\mathrm{CRH}$ in tilapia. This is corroborated by three further findings. First, the decrease in CRH content after 14$18 \mathrm{~min}(175 \mathrm{pg})$ was similar to the estimated amount of CRH which appeared in the plasma $(170 \mathrm{pg})$. Secondly, cortisol pretreatment concurrently abolished both the plasma CRH elevation and the drop in the posterior telencephalic CRH content. Thirdly, we showed that the ventral telencephalon of tilapia displays a strikingly high blood vascularisation, which confirms previous observations in other fish (Weiger et al. 1998, Butler 2000). In particular the ventrolateral telencephalic area in which the $\mathrm{CRH}$-ir cells are located in tilapia contains a plexus of blood capillaries, which are drained via the lateral telencephalic vein (Weiger et al. 1998).

To examine routes via which the $\mathrm{Vl}$ might receive inhibitory cortisol input, the distribution of GR in the brain was studied. The overall distribution pattern in tilapia is in line with the in situ hybridisation and immunohistochemical results in trout (Teitsma et al. 1997 , 1998), which also demonstrated predominant GR-ir cell clusters in the dorsal telencephalon, in the npo, in the nlt, in the inferior lobe of the hypothalamus (LIH) and in the cerebellum.

Recently Greenwood et al. (2003) characterised three corticosteroid receptors in H. burtoni: GR1, GR2 and a mineralocorticoid receptor (MR). Two GRs and a MR have also been reported in rainbow trout (Bury et al. 2003), but to date in tilapia only one of these receptors has been partially cloned (Tagawa et al. 1997), most likely the tilapia equivalent of the Haplochromis GR1 (Greenwood et al. 2003). As the antibody used in the present study was raised against the ab-domain of trout GR1 (Tujague et al. 1998, Bury et al. 2003) equivalent it is unlikely that it detected a putative tilapia MR given the low homology between the ab-domains of GR and MR in both $H$. burtoni and trout. Although in contrast to the DNA-binding domain the GR ab-domain varies between species, the N-terminal region of the latter domain appears more conserved. As discussed by Greenwood et al. (2003) and Bury et al. (2003), GR gene duplication probably has occurred throughout the teleost lineage, in which case our results include cells expressing GR1 and those expressing GR2.
The cytoplasmic location of the GR signal in our fish corroborates results in gill tissue of tilapia, rainbow trout and Atlantic salmon (Dang et al. 2000), but contrasts with results in trout (Teitsma et al. 1998), which may relate to the immunohistochemical methodology used or to physiological characteristics (developmental stage) of the fish used. Notably, during spawning migration of Kokanee salmon, Carruth et al. (2000) observed a shift of the GR signal from the cytoplasm to the nucleus.

Despite the overall similarity in GR brain distribution between trout and tilapia there were some species differences. The second and third gustatory centres were GR-positive in tilapia but not in trout. This difference may relate to the regulation of feeding behaviour during mouthbreeding of eggs, unique for cichlids. In tilapia the second and third gustatory centres project into the Dmd and receive input from the vagal lobe (Yoshimoto et al. 1998); the latter has been related to the cessation of feeding behaviour and inhibition of the swallowing reflex, which are critical for the survival of the eggs and larvae during mouthbreeding (Pepels et al. 2002a). The posterior part of the vagal lobe of tilapia, but not of salmonids, contains many CRH-ir fibres and terminals (Pepels et al. 2002a). The inhibitory role of CRH on feeding in fish has been demonstrated by intracerebro-ventricular $\mathrm{CRH}$ administration (De-Pedro et al. 1993).

In tilapia, as in trout, colocalisation of $\mathrm{CRH}$ and GR was observed in cells in the npo and nlt, which substantiate previous observations that cortisol feedback can be exerted at the level of the hypothalamus (Fryer \& Peter 1977) and nucleus preopticus (Fryer \& Peter 1977, Olivereau \& Olivereau 1988, Bernier et al. 1999) in fish. Additionally in tilapia very few cells dorsal to Vl were GR-positive, but it is unlikely that the cortisol effects observed were directed on these cells. Also in mammals cortisol feedback is exerted indirectly. The pvn is moderately rich in GR receptors, but basal levels of corticosterone first act at the hippocampus, which tonically inhibits the pvn (reviewed by De Kloet et al. 1998). In tilapia a telencephalic structure via which cortisol feedback to the $\mathrm{Vl}$ can be exerted is the medial part of the dorsal telencephalon, because the Dm contains a large group of GR-ir cells, and Dm has efferents to Vl (Murakami et al. 1983). Interestingly, Dm not

\footnotetext{
Figure 5 Micrographs of brain and pituitary sections. White arrowheads indicate blood capillaries and asterisks indicate lateral telencephalic veins. (A) A transverse overview through the right telencephalon at the level of the VI region showing a GR-ir cell cluster in Dmd, scattered GR-ir cells dorsal to Vl, GR-ir cells in Vs, a plexus of blood capillaries in VI and the lateral telencephalic veins. (B and C) Comparison of adjacent lateral sagital sections of the telencephalon showing $\mathrm{CRH}$-ir cells in $\mathrm{VI}(\mathrm{C})$, but no GR-ir cells (B) are present in the posterior part of Vl. GR-ir cells are located dorsally from VI (B). Very few CRH-ir cells showed GR-ir as shown by the arrow in (B and C). Left and right side of each photograph represents the posterior and anterior side respectively. (D) A transverse section through the right telencephalon showing the plexus of blood capillaries (arrowheads) close to the CRH-ir cells and CRH-ir terminals in VI. The plexus is drained via the lateral telencephalic veins. (E) A transverse section showing GR-ir in the cytoplasm of large round perikarya situated in the Dmd region of the telencephalon. (F) A transverse section showing small pyriform GR-ir cells in the lateral and medial part of the nucleus tuberis lateralis. (G) A transverse section through the pre-optic region showing GR-ir in magnocellular and parvocellular cells. (H and I) Comparison of adjacent sagital pituitary sections showing $\alpha$-MSH-ir cells $(\mathrm{H})$ and GR-ir cells (I). Arrows indicate $\alpha$-MSH-ir cells in the pars intermedia (H) that are GR-positive (white arrows) or GR-negative (black arrows) in the adjacent section (I) Black arrowheads indicate GR-positive cells that are not $\alpha$-MSH-positive. See Fig. 4 legend for abbreviations.
} 
only processes gustatory information but also acousticolateral signals from the lateral line system, an important sensory warning and orientation system for fish (Meek \& Nieuwenhuys 1998). Efferents of the Dm may either directly inhibit CRH-positive cells in the $\mathrm{Vl}$ or may inhibit the noradrenergic input that is present in the ventral telencephalon of fish (Meek et al. 1993). Recently we showed that in tilapia in vitro telencephalic $\mathrm{CRH}$ release is stimulated by noradrenaline (Pepels et al. 2004), which is consistent with the possibility that in vivo release from the $\mathrm{Vl}$ during stress is under adrenergic control.

The relatively low numbers of GR-ir cells that were found in the rostral pars distalis (Rpd) of the pituitary gland is related to the low number of corticotrophs present in the Rpd and is also in line with the very low innervation of the Rpd by CRH-ir terminals (Pepels et al. 2002a). Also in trout the corticotrophs are GR-positive (Teitsma et al. 1998). The identity of the GR-ir cells in the Ppd of the pituitary, which contains gonadotrophs, thyrotrophs and somatotrophs, is unclear but in trout both types of gonadotrophs display GR-ir (Teitsma et al. 1999). In the pars intermedia of the pituitary of tilapia subpopulations of the SL cells and of the melanotrophs contained GR, which supports previous physiological studies in teleost fish. Cortisol administered in vivo or in vitro (Balm et al. 1993) inhibited the $\mathrm{CRH}$-stimulated in vitro $\alpha-\mathrm{MSH}$ release from tilapia pars intermedia lobes. Induction of GR expression in rat MSH cells by stressors has been shown by Antakly et al. (1985). The release of SL, a member of the growth hormone/prolactin family unique for teleosts (Wendelaar Bonga 1997), is also influenced by stressors (Rand-Weaver et al. 1993).

\section{Function}

It is evident that plasma CRH is involved in the regulation of stress-related peripheral processes as unstressed tilapia had undetected $\mathrm{CRH}$ levels and plasma $\mathrm{CRH}$ levels increased after acute stress, whereas this increase was absent after chronic stress of $48 \mathrm{~h}$ or after cortisol pretreatment. Peripheral actions of plasma CRH are consistent with the expression of CRH receptors in heart, gills (Pohl et al. 2001) and spleen (Arai et al. 2001) of fish. We have no evidence for direct actions of $\mathrm{CRH}$ or of $\mathrm{CRH}$ in combination with a subsequent ACTH pulse on the interrenal cells, but $\mathrm{CRH}$ could regulate circulating leukocytes during stress, as $\mathrm{CRH}$ stimulates activated peripheral leukocytes of channel catfish (Ictalurus punctatus) in vitro to secrete ACTH-ir (Arnold \& Rice 2000). $\mathrm{CRH}$ concentrations as low as $50 \mathrm{pg} / \mathrm{ml}$ modulate interleukin-1 $\beta$ production by cultures of peripheral human blood monocytes (Pereda et al. 1995). Also circulating $\mathrm{CRH}$ may regulate cardiac output during stress. In the catfish Ameiurus nebulosus (Arai et al. 2001) and in salmon Oncorhynchus keta (Pohl et al. 2001), CRH-R2 are most abundantly expressed peripherally in the atrium. In contrast to mammals the fish CRF-R1 and R2 receptors display similar affinities to U-I and to CRH (Arai et al. 2001). As reported plasma levels of U-I in fish do not exceed $80 \mathrm{pg} / \mathrm{ml}$ (Suess et al. 1986), CRH-R2 in the atrium could transduce the plasma CRH signal (600 pg/ $\mathrm{ml})$ during stress. Haemodynamic actions of $\mathrm{CRH}$ have also been reported to increase corticosteroid release (van Oers et al. 1992). In this case the peptide forms part of a neuroendocrine circuit involving CRH-producing cells in the adrenal gland. Activation of this circuit increases bloodflow, which in turn leads to elevated corticosteroid release (van Oers et al. 1992). Notably the headkidneys of unstressed tilapia contained $\mathrm{CRH}$, which strongly suggests that the peptide is locally produced in this organ, as in these fish plasma CRH levels were below the level of detection.

In tilapia (Pepels et al. 2002a) and in other teleosts species (Lovejoy \& Balment 1999) descending spinal $\mathrm{CRH}$-ir projections appear to be absent in contrast to the mammalian brain where descending $\mathrm{CRH}$-ir projections into the medulla and the spinal cord have been described. These eventually terminate upon cell groups that innervate smooth and cardiac muscle, various glands and body viscera (Sawchenko \& Swanson 1985). Possibly in teleosts some autonomic CRH actions during stress are regulated by circulating $\mathrm{CRH}$, whereas the descending neural $\mathrm{CRH}$ projection evolved later during evolution.

\section{Acknowledgements}

We gratefully acknowledge Tony Coenen for his contribution to the immunohistochemical work, Dr Liesbeth Pierson and Gerard Dekkers for their photo-technical assistance, Dr J Meek for neuroanatomical advice, Dr B Ducouret from the University of Rennes, France for the gift of the GR antiserum and Gerard Pesman from the University Medical Centre, St Radboud Hospital, Nijmegen for his advice regarding CRH characterisation.

\section{References}

Antakly T, Sasaki A, Liotta AS, Palkovits M \& Krieger DT 1985 Induced expression of the glucocorticoid receptor in the rat intermediate pituitary lobe. Science 19 277-279.

Arai M, Assil IQ \& Abou-Samra AB 2001 Characterisation of CRF-receptors in catfish: a novel receptor is predominantly expressed in pituitary and urophysis. Endocrinology 142 446-454.

Arnold RE \& Rice CD 2000 Channel catfish, Ictalurus punctatus, leukocytes secrete immunoreactive adrenal corticotropin hormone (ACTH). Fish Physiology and Biochemistry 22 303-310.

Balm PHM, Groneveld D, Lamers AE \& Wendelaar Bonga SE 1993 Multiple actions of melanotropic peptides in the teleost Oreochromis mossambicus (tilapia). Annals of the New York Academy of Sciences $\mathbf{6 8 0}$ 448-450.

Balm PHM, Pepels P, Helfrich S, Hovens MLM \& Wendelaar Bonga SE 1994 Adrenocorticotropic hormone in relation to interrenal function during stress in tilapia (Oreochromis mossambicus). General and Comparative Endocrinology 96 347-360. 
Bernier NJ, Lin XW \& Peter RE 1999 Differential expression of corticotropin-releasing factor (CRF) and urotensin I precursor genes, and evidence of CRF gene expression regulated by cortisol in goldfish brain. General and Comparative Endocrinology 116 461-477.

Bury NR, Sturm A, Le-Rouzic P, Lethimonier C, Ducouret B, Guiguen Y, Robinson-Rechavi M, Laudet V, Rafestin-Oblin ME \& Prunet P 2003 Evidence for two distinct functional glucocorticoid receptors in teleost fish. Journal of Molecular Endocrinology 31 141-156.

Butler AB 2000 Topography and topology of the teleost telencephalon: a paradox resolved. Neuroscience Letters 293 95-98.

Carruth LL, Jones RE \& Norris DO 2000 Cell density and intracellular translocation of glucocorticoid receptor-immunoreactive neurons in the kokanee salmon (Oncorhynchus nerka kennerlyi) brain, with an emphasis on the olfactory system. General and Comparative Endocrinology 117 66-76.

Catalan R, Gallart JM, Castellanos JM \& Galard R 1998 Plasma corticotropin-releasing factor in depressive disorders. Biological Psychiatry 44 15-20.

Dang ZC 2000 Adaptive stress response in fish gills. Thesis. Enschede, The Netherlands: Ipskamp Publishing Co.

De Kloet ER, Vreugdenhil E, Oitzl MS \& Joels M 1998 Brain corticosteroid receptor balance in health and disease. Endocrine Reviews 19 269-301.

Denver RJ 1997 Environmental stress as a developmental cue: corticotropin releasing hormone is a proximate mediator of adaptive phenotypic plasticity in amphibian metamorphosis. Hormones and Behaviour 31 169-179.

De-Pedro N, Alonso-Gomez AL, Gancedo B, Delgado M-J \& Alonso-Bedate M 1993 Role of corticotropin-releasing factor (CRF) as a food intake regulator in goldfish. Physiology and Behavior 53 517-520.

Fridberg G, Nishioka RS, Bern HA \& Fleming WR 1966 Regeneration of the caudal neurosecretory system in the cichlid teleost Tilapia mossambica. Journal of Experimental Zoology 162 311-366.

Fryer J \& Peter R 1977 Hypothalamic control of ACTH secretion in goldfish. III. Hypothalamic cortisol implant studies. General and Comparative Endocrinology 33 215-225.

Greenwood AK, Butler PC, White RB, DeMarco U, Pearce D \& Fernald RD 2003 Multiple corticosteroid receptors in a teleost fish: distinct sequences, expression patterns and transcriptional activities. Endocrinology 144 4226-4236.

Hauger RL, Thrivikraman KV \& PM Plotsky 1994 Age-related alterations of hypothalamic-pituitary-adrenal axis functioning in male Fisher rats. Endocrinology 134 1528-1536.

Kelsall CJ \& Balment RJ 1998 Native urotensins influence cortisol secretion and plasma cortisol concentration in the euryhaline flounder, Platichthys flesus. General and Comparative Endocrinology 112 210-219.

Kemp CF, Woods RJ \& Lowry PJ 1998 The corticotrophin-releasing factor-binding protein: an act of several parts. Peptides 19 1119-1128.

Linton EA, Perkins AV, Hagan P, Poole S, Bristow AF, Tilders F, Corder R \& Wolfe CD 1995 Corticotrophin-releasing hormone $(\mathrm{CRH})$-binding protein interference with $\mathrm{CRH}$ antibody binding: implications for direct CRH immunoassay. Journal of Endocrinology 146 45-53.

Lovejoy DA \& Balment RJ 1999 Evolution and physiology of the corticotropin-releasing factor (CRF) family of neuropeptides in vertebrates. General and Comparative Endocrinology 115 $1-22$.

McLean M, Bisits A, Davies J, Woods R, Lowry P \& Smith R 1995 A placental clock controlling the length of human pregnancy. Nature Medicine 1 460-463.
Meek J \& Nieuwenhuys R 1998 Holosteans and teleost. In The Central Nervous System of Vertebrates, pp 758-937. Eds R Nieuwenhuys, HJ Ten Donkelaar \& C Nicholson. New York: Springer Verlag.

Meek J, Joosten HWJ \& Hafmans TGM 1993 Distribution of noradrenaline-immunoreactivity in the brain of the mormyrid teleost Gnathonemus petersii. Journal of Comparative Neurology 328 145-160.

Murakami T, Morita Y \& Ito H 1983 Extrinsic and intrinsic fiber connections of the telencephalon in a teleost, Sebastiscus marmoratus. Journal of Comparative Neurology 216 115-131.

Nishioka T, Iyota K, Nakayama T, Suemaru S, Numata Y \& Hashimoto K 1993 Effects of ether-laparotomy and water immersion-restraint stress on CRH concentration in the hypothalamus, extrahypothalamic tissues and peripheral blood. Endocrine Journal 40 213-220.

Okimoto DK, Distefano JJ, Kuwaye TT, Ron B, Weber GM, Nguyen TT \& Grau EG 1994 On plasma volume measurement and the effect of experimental stress in male tilapia, Oreochromis mossambicus, maintained in fresh water. Fish Physiology and Biochemistry 12 431-438.

Olivereau M \& Olivereau J 1988 Quantitative changes of CRF-like immunoreactivity in eels treated with reserpine and cortisol. Peptides 9 1261-1267.

Orth DN \& Mount CD 1987 Specific high-affinity binding protein for human corticotropin-releasing hormone in normal human plasma. Biochemical and Biophysical Research Communications 143 411-417.

Pepels P, Meek J, Wendelaar Bonga SE \& Balm PHM 2002a Distribution and quantification of corticotropin-releasing hormone $(\mathrm{CRH})$ in the brain of the teleost fish Oreochromis mossambicus (tilapia). Journal of Comparative Neurology 453 247-268.

Pepels P, Pesman G, Korsten H, Wendelaar Bonga SE \& Balm PHM $2002 b$ Corticotropin-releasing hormone (CRH) in the teleost fish Oreochromis mossambicus (tilapia): in vitro release and brain distribution determined by a novel radioimmunoassay. Peptides $\mathbf{2 3}$ 1053-1062.

Pepels PPLM, Wendelaar Bonga SE \& Balm PHM 2004 Bacterial lipopolysaccharide (LPS) modulates corticotropin-releasing hormone $(\mathrm{CRH})$ content and release in the brain of juvenile and adult tilapia (Oreochromis mossambicus; Teleostei). Journal of Experimental Biology (In Press).

Pereda MP, Sauer J, Castro CP, Finkielman S, Stalla GK, Holsboer F \& Arzt E 1995 Corticotropin-releasing hormone differentially modulates the interleukin-1 system according to the level of monocyte activation by endotoxin. Endocrinology 136 5504-5510.

Pohl S, Darlinson MG, Clarke WC, Lederis K \& Richter D 2001 Cloning and functional pharmacology of two corticotropin releasing factor receptors from a teleost fish. European Journal of Pharmacolog 430 193-202.

Quabius ES, Balm PHM \& Wendelaar Bonga SE 1997 Interrenal stress responsiveness of tilapia (Oreochromis mossambicus) is impaired by dietary exposure to PCB 126. General and Comparative Endocrinology 108 472-482.

Rand-Weaver M, Pottinger TG \& Sumpter JP 1993 Plasma somatolactin concentrations in salmonid fish are elevated by stress. Journal of Endocrinology 138 509-515.

Sawchenko PE \& Swanson LW 1985 Localisation, colocalisation, and plasticity of corticotropin-releasing factor immunoreactvity in rat brain. Federation Proceedings 44 221-227.

Seasholtz AF, Valverde RA \& Denver RJ 2002

Corticotropin-releasing hormone-binding protein: biochemistry and function from fishes to mammals. Journal of Endocrinology $\mathbf{1 7 5}$ 89-97.

Stalla GK, Stalla J, Schopohl J, von-Werder K \& Muller OA 1986 Corticotropin releasing factor in humans: CRF stimulation in normals and CRF radioimmunoassay. Hormone Research 24 $229-245$ 
Suess U, Lawrence J, Ko D \& Lederis K 1986 Radioimmunoassays for fish tail neuropeptides: development of assay and measurement of immunoreactive urotensin I in Catostomus commersoni brain, pituitary, and plasma. Journal of Pharmacological Methods 15 335-346.

Sumitomo T, Suda T, Tomori N, Yajima F, Nakagami Y, Ushiyama T, Demura H \& Shizume K 1987 Immunoreactive corticotropin-releasing factor in rat plasma. Endocrinology 120 1391-1396.

Tagawa M, Hagiwara H, Takemura A, Hirose S \& Hirano T 1997 Partial cloning of the hormone-binding domain of the cortisol receptor in tilapia, Oreochromis mossambicus, and changes in the mRNA level during embryonic development. General and Comparative Endocrinology 108 132-140.

Teitsma CA, Bailhache T, Tujague M, Balment RJ, Ducouret B \& Kah O 1997 Distribution and expression of glucocorticoid receptor mRNA in the forebrain of the rainbow trout. Neuroendocrinology 66 294-304.

Teitsma CA, Anglade I, Toutirais G, Munoz Cueto JA, Saligaut D, Ducouret B \& Kah O 1998 Immunohistochemical localization of glucocorticoid receptors in the forebrain of the rainbow trout (Oncorhynchus mykiss). Journal of Comparative Neurology 401 395-410.

Teitsma CA, Anglade I, Lethimonier C, Le-Drean G, Saligaut D, Ducouret B \& Kah O 1999 Glucocorticoid receptor immunoreactivity in neurons and pituitary cells implicated in reproductive functions in rainbow trout: a double immunohistochemical study. Biology of Reproduction 60 642-650.

Tujague M, Saligaut D, Teitsma C, Kah O, Valotaire Y \& Ducouret B 1998 Rainbow trout glucocorticoid receptor overexpression in
Escherichia coli: production of antibodies for Western blotting and immunohistochemistry. General and Comparative Endocrinology 110 201-211.

van Enckevort FHJ, Pepels PPLM, Leunissen JAM, Martens GJM, Wendelaar Bonga SE \& Balm PHM 2000 Oreochromis mossambicus (tilapia) corticotropin-releasing hormone: cDNA sequence and bioactivity. Journal of Neuroendocrinology 12 177-186.

van Oers JW, Hinson JP, Binnekade R \& Tilders RJ 1992 Physiological role of corticotropin-releasing factor in the control of adrenocorticotropin-mediated corticosterone release from the rat adrenal gland. Endocrinology 130 282-288.

Weiger T, Lametschwandtner A, Kotrschal K \& Krautgartner WD 1988 Vascularization of the telencephalic choroid-plexus of a ganoid fish Acipenser ruthenus (L). American Journal of Anatomy 182 33-41.

Wendelaar Bonga SE 1997 The stress response in fish. Physiological Reviews 77 591-625.

Yokoe T, Audhya T, Brown C, Hutchinson B, Passarelli J \& Hollander CS 1988 Corticotropin-releasing factor levels in the peripheral plasma and hypothalamus of the rat vary in parallel with changes in the pituitary-adrenal axis. Endocrinology 123 1348-1354.

Yoshimoto M, Albert JS, Sawai N, Shimizu M, Yamamoto N \& Ito H 1998 Telencephalic ascending gustatory system in a cichlid fish, Oreochromis (Tilapia) niloticus. Journal of Comparative Neurology 392 209-226.

Received in final form 11 November 2003 Accepted 21 November 2003 